\title{
SOLUTIONS AND EFFECTIVENESS OF WATER PROTECTION STRUCTURES IN FOREST DRAINAGE SYSTEM MAINTENANCE: EXAMPLES FROM LATVIA
}

Zane KL,AVIN̦A, Latvian State Forest Research Institute "Silava”, 111 Rigas str, Salaspils, LV-2169, Latvia / University of Latvia, Raina Blvd. 19, Riga, LV-1586, Latvia, zane.kalvite@ silava.lv (corresponding author)

Ivars KḶAVIN̦Š, Latvian State Forest Research Institute "Silava", 111 Rigas str, Salaspils, LV-2169, Latvia / University of Latvia, Raina Blvd. 19, Riga, LV-1586, Latvia, ivars.klavins@silava.lv

\begin{abstract}
Drainage system maintenance (DNM) is essential for the main function of the drainage system - to drain excess water ensuring the growth of high quality forest stands. However, it can contribute to erosion and increase the discharge of suspended solids and nutrients from drainage network catchments. To avoid deterioration of water quality, water protection structures should be constructed while carrying out DNM. This paper presents preliminary effectiveness assessment of a custom sedimentation pond sized according to catchment area and the first peak flow control (PFC) structure built in production forests in Latvia. We compared changes of various chemical and physical parameters in periods before and after construction of water protection structures as well as evaluated the effectiveness of the structures during DNM. Slight increase of $\mathrm{pH}, \mathrm{N}-\mathrm{NH}_{4}{ }^{+}, \mathrm{N}_{-} \mathrm{NO}_{3}{ }^{-}$as well as slight decrease of $\mathrm{P}-\mathrm{PO}_{4}{ }^{3-}$ and $\mathrm{DOC}^{-}$was observed after DNM in affected sites. Sedimentation pond and PFC structure proved their effectiveness in reducing concentrations of suspended solids (by 62\% and by 65\% respectively). Retention of nutrients in the structures was not significant, furthermore, mean nutrient concentrations during sampling period in all study sites were generally low. As nutrient accumulation by the living vegetation (that is not yet developed) is an important facet of the nutrient retention, sampling and assessment of effectiveness of the constructed water protection structures is still ongoing. In addition, study is being continued to further assess DNM impact on water quality.
\end{abstract}

Keywords: water protection, water quality, drainage network, forestland, sedimentation pond, peak flow control structure

\section{INTRODUCTION}

In Latvia, forests cover approximately $52 \%$ of the total area (State Forest Service, 2021). Furthermore, with more than 12000 rivers, streams, large ditches and more than 4000 lakes Latvia is rich in water resources. In general, 30\% of surface waterbodies in Latvia correspond to high or good ecological quality according to the results of surface water quality monitoring in 2019 (LEGMC, 2020). Forestry related operations, especially harvesting (Nieminen, 2004), drainage of peat soils (Nieminen et al., 2010) and drainage network maintenance (Joensuu et al., 1999), may adversely impact water quality by increasing loads of sediments and nutrients in downstream waterbodies (Joensuu et al., 2002; Nieminen et al., 2010). Due to growing demand for renewable bioenergy in addition to commercial timber, it is likely that the pressure on production forests will increase, and it may affect also water ecosystems. Therefore, the impact of forest management on water quality should be assessed and environmental considerations included in planning and implementation of forestry operations.

Drainage network maintenance (DNM) is crucial in maintaining forest productivity, as well as in ensuring secure access to forest resources. Approximately 10 out of 15 million ha of paludified mineral soils and peatlands drained for forestry purposes in the temperate and boreal regions are located in the Baltic Sea Region countries (Paavilainen \& Päivänen, 1995), and these drained peatlands significantly contribute to nutrient export from forest land (Nieminen et al., 2017b). Potentially negative impacts on water quality should be minimized, and one of the solutions is construction of water protection structures that reduce water flow rate and trap sediments and nutrients. Water protection structures, also known as blue-green infrastructure solutions, are the preferred mitigation measures for protection the receiving water bodies from peak runoff volumes and elevated loadings (Meland, 2016). Different solutions are being tested and implemented worldwide (e.g., Grung et al., 2021; Tunçsiper, 2020; Zapico et al., 2021) to minimize impact from various sources (such as agriculture, forestry, mining, road runoff, etc.).

Wetland buffers or overland flow areas have very high effectiveness (Kløve, 2000; Hynninen et al., 2011), although their use is limited in operational forestry, especially in flat areas and pristine sites. They are constructed by directing the waters from forested catchments into a wetland buffer area. Another practice is establishment of sedimentation pits (small widened and deepened sections of ditches) for reducing the flow rate and capturing suspended solids, as well as sedimentation ponds - artificial structures designed as longer widened and deepened segments of the

Copyright (C) 2021 The Authors. Published by Vytautas Magnus University. This is an open-access article distributed under the terms of the Creative Commons Attribution License (CC BY 4.0), which permits unrestricted use, distribution, and reproduction in any medium, provided the original author and source are credited. 
ditch to retain surface runoff and to trap sediments by gravity before the water enters the natural stream (Albert et al., 1988). Due to the potential of conserving and promoting aquatic biodiversity, sedimentation ponds have gained interest in an ecological context (Le Viol et al., 2009; Meland et al., 2020). Sun et al. (2018) pointed out that large enough sedimentation ponds are likely to provide a more heterogeneous environment and thereby contain a species-rich fauna. Another solution is a peak flow control structure (PFC). Marttila \& Kløve (2010) in Finland concluded that in peatland forestry PFC works effectively as a water protection structure. Such peak control structures are designed differently, adapting to the site specifics - catchment size, average slope and precipitation patterns. Usually a sedimentation pond is combined with a dam with runoff regulating pipes below the pond. However, such a structure should not be chosen as the only water protection structure, if the loads of dissolved elements from the catchment area are high (Finér et al., 2018).

In Latvia, sedimentation ponds are constructed for sedimentation and biological accumulation from agricultural and forest land drainage systems. Their parameters are fixed depending on the length of the drainage system to be renovated - a sedimentation basin must be built in a 30-50 m long section, creating a $0.5-1.0 \mathrm{~m}$ recess $(0.5-4 \mathrm{~m}$ in a raised moss bog used in agriculture or in an exploited peat bog). The bottom of the sedimentation pond must be at least $2 \mathrm{~m}$ wider than the bottom of the inflowing ditch to be cleaned (Cabinet of Ministers, 2014). A previous study in six drainage network maintenance sites in state forests in Latvia concluded that the efficiency of standard-size sedimentation ponds was higher in reducing the concentrations of suspended particles than in reducing the concentrations of nutrients (Kalvite et al., 2019). Following these results, testing of potentially more effective solutions, such as custom-sized sedimentation pond and a peak-flow control structure, was started recently, and preliminary results on their effectiveness are reported in this article.

\section{MATERIALS AND METHODS}

\section{Sampling sites}

The effectiveness of custom sedimentation pond and PFC structure was studied in the eastern part of Latvia, in experimental forests of the Kalsnava Forest district, where a dense drainage ditch network is present in the area (Figure 1 and Figure 2). Study was conducted on peat soils, with sand of varying roughness in the bedrock.

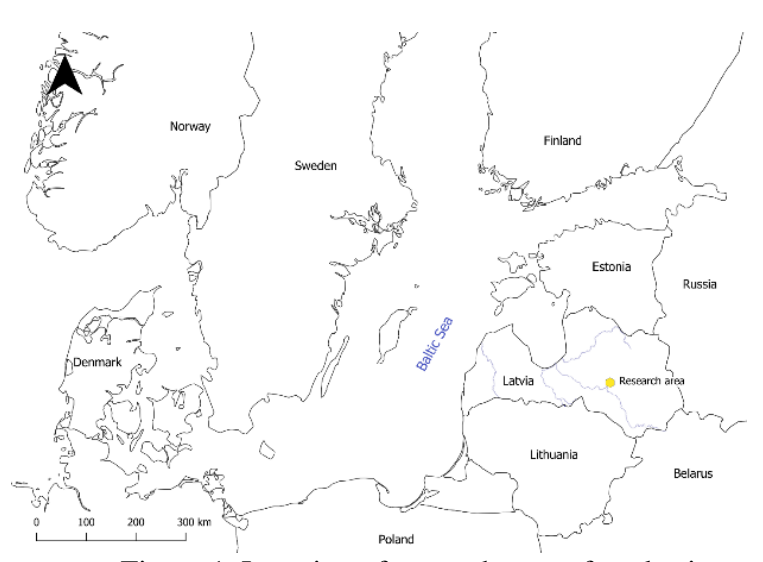

Figure 1. Location of research area of study sites.

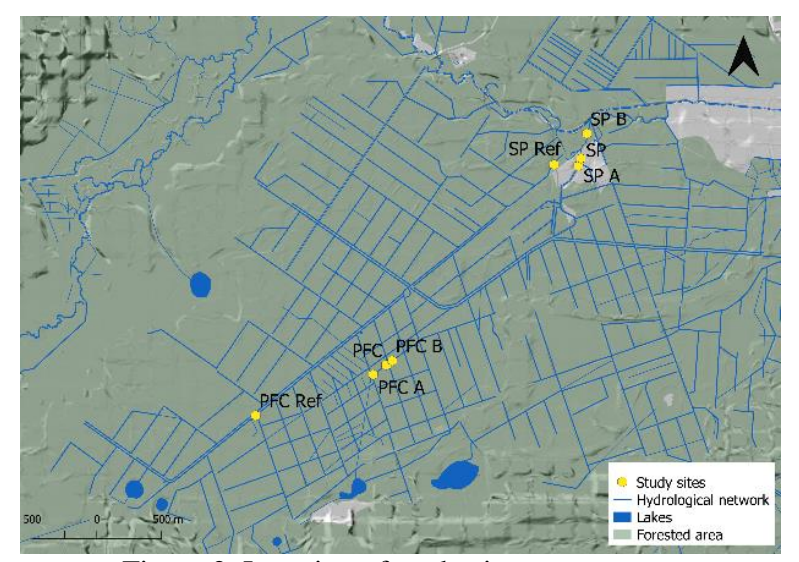

Figure 2. Location of study sites

In a drainage network catchment of total area 791.3 ha DNM was started in August 2020. First, the custom sedimentation pond was constructed in the lowest part of the catchment close to the receiving waterbody Veseta (section of this river has been determined as Priority Fish Water (Cabinet of Ministers, 2002)). The sedimentation pond was designed to be of irregular shape, and its size was adjusted to be at least $3 \mathrm{~m}^{2}$ per one ha of the catchment area. As there was sufficient space, the pond was excavated with the total surface area of 0.34 ha resulting in $4.3 \mathrm{~m}^{2}$ per ha of the catchment area. Boulder stack was installed at the outlet.

The DNM operations were continued upstream from the sedimentation pond to the place of planned PFC structure. The operating catchment area corresponding to the structure is 314.1 ha. Construction works of PFC structure were carried out in January and February 2021. The constructed PFC structure consists of a sedimentation pond with surface area of 0.06 ha and a dam with flow control pipes. At the dam a main flow pipe was installed with a downward facing obstruction barrier towards the pond, as well as two emergency overflow pipes $\sim 50 \mathrm{~cm}$ above the main pipe. In the end of February 2021 DNM works in the catchment were finished.

To evaluate the effectiveness of the structures sampling was started in April 2019 in sites SP A, SP B and PFC prior to DNM as well as in the reference site SP R to consider seasonal variation (Table 1). In August 2020 when sedimentation pond was constructed sampling was started in site SP. In May 2020 sampling was started in reference site PFC R closer to the PFC structure (upstream in the same catchment where no DNM activities were present), also to consider seasonal variation. In January 2021 when PFC structure was constructed, sampling was started in sites PFC A and PFC B. 


\begin{tabular}{|c|c|c|c|c|}
\hline $\begin{array}{l}\text { Study } \\
\text { site }\end{array}$ & $\begin{array}{l}\text { Sampling } \\
\text { point } \\
\text { coordinates } \\
\text { (latitude; } \\
\text { longitude) } \\
\end{array}$ & Description & Sampling point/ date when sampling was started & $\begin{array}{l}\text { Mean flow } \\
\text { velocity } \\
\text { (min-max } \\
\text { values), } \mathrm{m} / \mathrm{s}\end{array}$ \\
\hline SP & $\begin{array}{l}56.6972^{\circ} \mathrm{N} \\
25.8650^{\circ} \mathrm{E}\end{array}$ & $\begin{array}{l}\text { Constructed } \\
\text { sedimentation pond. }\end{array}$ & In sedimentation pond./ 11.08.2020. & - \\
\hline SP A & $\begin{array}{l}56.6967^{\circ} \mathrm{N} \\
25.8646^{\circ} \mathrm{E}\end{array}$ & $\begin{array}{l}\text { Inflow ditch of } \\
\text { sedimentation pond. }\end{array}$ & $\begin{array}{l}\text { "A" means "above". Before construction of sedimentation } \\
\text { pond, sampling was done in drainage ditch } \sim 5 \mathrm{~m} \text { above the } \\
\text { planned construction location. After construction of } \\
\text { sedimentation pond, sampling was done approximately at the } \\
\text { same point./ 03.04.2019. }\end{array}$ & $0.3(0-0.6)$ \\
\hline SP B & $\begin{array}{l}56.6989^{\circ} \mathrm{N} \\
25.8658^{\circ} \mathrm{E}\end{array}$ & $\begin{array}{lr}\text { Uncleaned } & \text { outflow } \\
\text { ditch } & \text { of } \\
\text { sedimentation pond. }\end{array}$ & $\begin{array}{l}\text { "B" means "below". Before construction of sedimentation } \\
\text { pond, sampling was done in drainage ditch } \sim 130 \mathrm{~m} \text { below the } \\
\text { planned construction location }(\sim 100 \mathrm{~m} \text { before ditch flows into } \\
\text { the river }) \text {. After construction of sedimentation pond, sampling } \\
\text { was done approximately at the same point./ } 03.04 .2019 \text {. }\end{array}$ & $0.2(0-0.5)$ \\
\hline SP R & $\begin{array}{l}56.6968^{\circ} \mathrm{N} \\
25.8616^{\circ} \mathrm{E}\end{array}$ & $\begin{array}{l}\text { No-DNM reference } \\
\text { site. Drainage ditch in } \\
\text { the drainage system } \\
\text { nearby sedimentation } \\
\text { pond. }\end{array}$ & In drainage ditch./ 03.04.2019. & $0.2(0-0.7)$ \\
\hline PFC & $\begin{array}{l}56.6832^{\circ} \mathrm{N} \\
25.8397^{\circ} \mathrm{E}\end{array}$ & $\begin{array}{l}\text { Peak flow control } \\
\text { structures' } \\
\text { sedimentation pond. }\end{array}$ & $\begin{array}{l}\text { In drainage ditch. After construction of peak flow control } \\
\text { structure, sampling was done in peak flow control structures' } \\
\text { pond in about the same place/ } 03.04 .2019 \text {. }\end{array}$ & - \\
\hline PFC A & $\begin{array}{l}56.6826^{\circ} \mathrm{N} \\
25.8381^{\circ} \mathrm{E}\end{array}$ & $\begin{array}{l}\text { Inflow ditch of peak } \\
\text { flow control } \\
\text { structure. }\end{array}$ & $\begin{array}{l}\text { "A" means "above". Sampling was done in drainage ditch } \sim 5 \\
\mathrm{~m} \text { above the peak flow control structure./ 12.01.2021. }\end{array}$ & $0.2(0.1-0.4)$ \\
\hline PFC B & $\begin{array}{l}56.6835^{\circ} \mathrm{N} \\
25.8405^{\circ} \mathrm{E}\end{array}$ & $\begin{array}{l}\text { Outflow ditch of peak } \\
\text { flow control } \\
\text { structure. }\end{array}$ & $\begin{array}{l}\text { "B" means "below". Sampling was done in drainage ditch } \sim 10 \\
\text { m below peak flow control structure./ 12.01.2021. }\end{array}$ & $0.2(0.1-0.4)$ \\
\hline PFC R & $\begin{array}{l}56.6800^{\circ} \mathrm{N} \\
25.8231^{\circ} \mathrm{E}\end{array}$ & $\begin{array}{l}\text { No-DNM reference } \\
\text { site. Drainage ditch in } \\
\text { the same catchment } \\
\text { upstream where no } \\
\text { DNM activities were } \\
\text { carried out. }\end{array}$ & In drainage ditch./ 19.05.2020. & $0.2(0-0.9)$ \\
\hline
\end{tabular}

\section{Water sampling and chemical analyses}

Water samples for general chemistry analyses were taken once a month in sites (SP A, SP B, SP R, PFC) during the period from April 2019 to July 2021. Water samples in reference site (PFC R) were taken once a month during the period from May 2020 to July 2021. Water samples in Site PFC A and PFC B were taken once a month from January 2021 to July 2021. During the construction period of sedimentation pond and PFC structure, more frequent sampling was planned. Accordingly, during the period from June 2020 all samples were taken twice a month, from August - once a week, from March 2021 - twice a month again and from June 2021 - once a month.

With water sampling in a running watercourse water flow rate was measured using water velocity gauge $J D C$ Flowatch. The pH was determined according to Latvian Standard (LVS) ISO 10523:2012. The concentration of total nitrogen (TN), nitrate nitrogen $\left(\mathrm{N}_{-} \mathrm{NO}_{3}{ }^{-}\right)$and dissolved organic carbon (DOC) in water samples were determined using a FORMACSHT TOC/TN Analyser (ND25 nitrogen detector) according to LVS EN 12260:2004 and LVS EN 1484:2000, and ammonium nitrogen $\left(\mathrm{N}-\mathrm{NH}_{4}{ }^{+}\right.$) was determined using the spectrometric method according to LVS ISO 7150-1:1984. Total phosphorus (TP) and phosphate-phosphorus $\left(\mathrm{P}-\mathrm{PO}_{4}{ }^{3-}\right)$ were determined using an ammonium molybdate spectrometric method according to LVS EN ISO 6878:2005. The content of total suspended solids (TSS) was determined according to LVS EN 872:2007. Prior to the chemical analyses (excluding determination of pH and TSS), the water samples were filtered using borosilicate glass fibre filters without a binder. Preservation and handling of water samples was done according to ISO 5667-3:2012.

\section{Statistical analysis}

Data statistical analysis was conducted in R (R Development Core Team, 2020); "stats" (R Development Core Team, 2020) and "agricolae" (Mendiburu, 2020) packages were used. Because of the varying sampling intervals mean values for periods of 1 month were calculated (longest sampling period) prior to further analysis. Data were grouped into three periods - screening (only in site PFC), before construction and after construction for both water protection structures. To compare sampling sites analysis of variance (ANOVA) in combination with least significant difference (LSD) posthoc test was used. Statistical comparison of the means was conducted between study sites within corresponding periods as well as between periods to assess effects of DNM. To visualize the data "ggplot2" package was used (Wickham, 2016).

\section{RESULTS}




\section{Sedimentation pond}

Before and after construction of the sedimentation pond mean $\mathrm{pH}$ values were generally significantly higher ( $p$-values $<0.034$ ) in site SP R (Figure 3). Mean concentrations of $\mathrm{N}_{-} \mathrm{NH}_{4}{ }^{+}$(p-values $<0.046$ ), TN ( $p$-values 0.000$)$, TP ( $p$-values $<0.043$ ) and DOC ( $p$-values 0.000$)$ were generally significantly lower in site SP R compared to other study sites, but mean concentrations of $\mathrm{P}_{-} \mathrm{PO}_{4}{ }^{3-}$ were significantly lower ( $p$-values 0.000 ) only in the pre-construction period. Mean concentrations of DOC in the period after construction of the sedimentation pond have decreased in all study sites. Concentration of TSS was the only parameter that was significantly different when comparing study sites SP A and SP B.

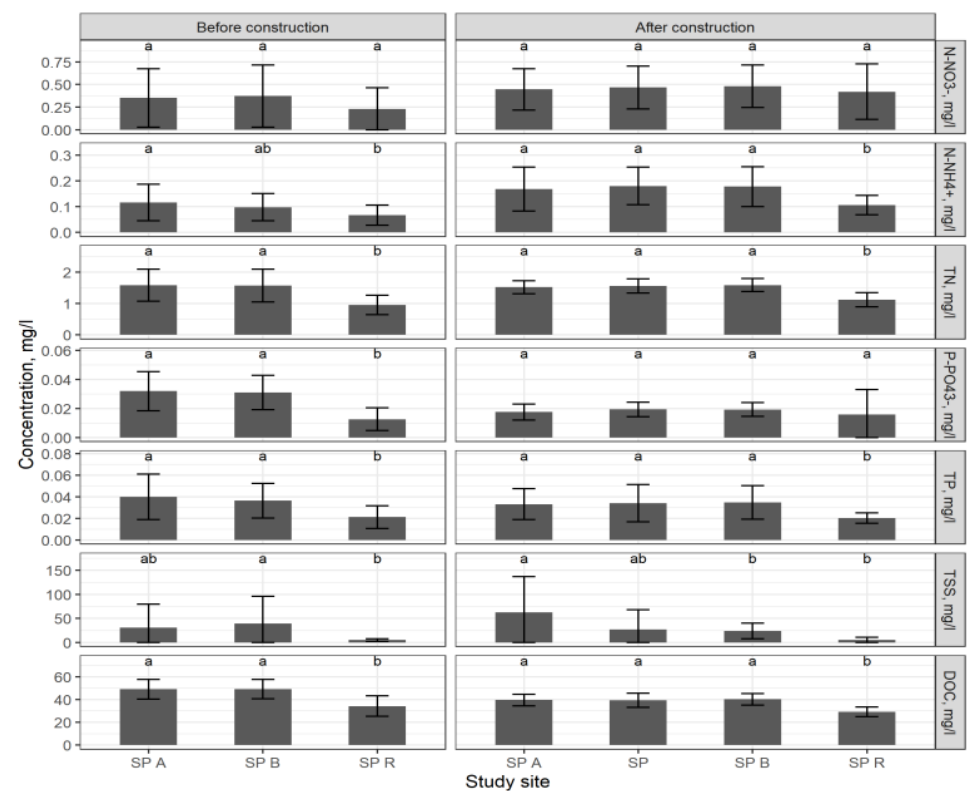

Figure 3. Average concentrations of $\mathrm{N}^{-\mathrm{NO}_{3}}{ }^{-}, \mathrm{N}-\mathrm{NH}_{4}{ }^{+}, \mathrm{TN}, \mathrm{P}-\mathrm{PO}_{4}{ }^{3-}, \mathrm{TP}, \mathrm{TSS}$ and DOC at study sites SP, SP A, SP B, SP R. Whiskers - standard deviation. Study sites with the same letter (above the columns) are not significantly different by ANOVA and LSD posthoc test; letters indicate differences within sites.

\section{Peak flow control structure}

Before construction of PFC structure, mean $\mathrm{pH}$ value and mean TN concentration in site PFC R was significantly lower comparing to site PFC ( $p$-values 0.005 and 0.003 respectively) (Figure 4). However, during the period after construction the mentioned statistically significant differences were no longer present. Concentrations of DOC were significantly lower in site PFC R both before and after construction of PFC structure ( $p$-values $<0.028$ ). In site PFC R almost all parameters (except $\mathrm{pH}$ ) were slightly lower in the period before construction of the PFC structure. Similarly, as with the sedimentation pond, TSS concentrations had decreased notably in site PFC B if compared to site PFC A, but the differences were not statistically significant, due to the large variation in concentrations.

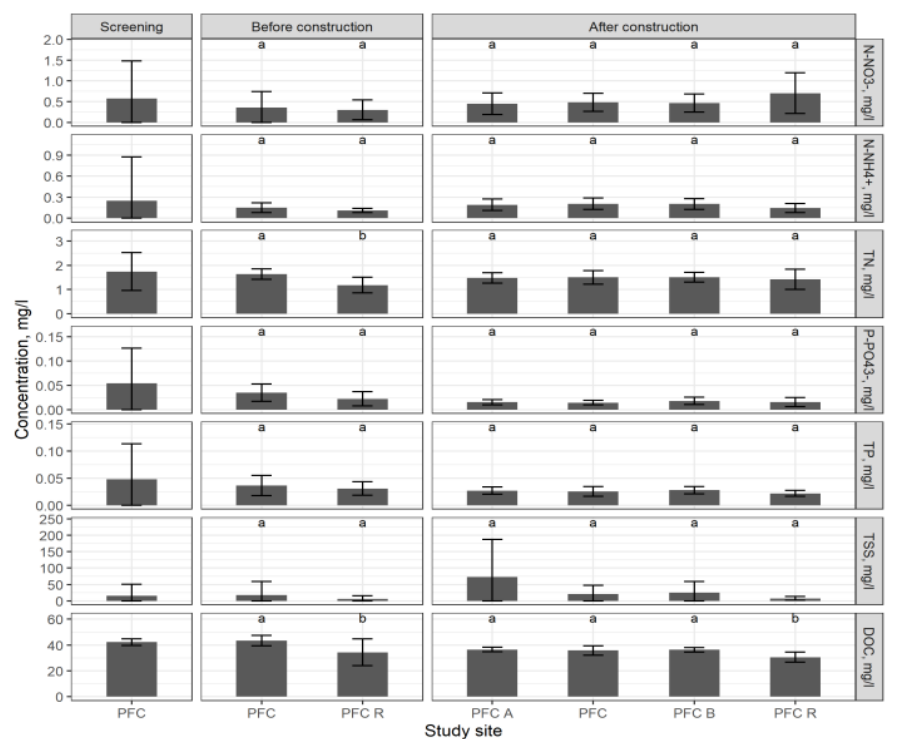

Figure 4. Average concentrations of $\mathrm{N}_{-} \mathrm{NO}_{3}{ }^{-}, \mathrm{N}_{-} \mathrm{NH}_{4}{ }^{+}, \mathrm{TN}, \mathrm{P}-\mathrm{PO}_{4}{ }^{3-}$, TP, TSS and DOC at study sites PFC A, PFC B, PFC and PFC R. Whiskers - standard deviation. Study sites with the same letter (above the columns) are not significantly different by ANOVA and LSD post-hoc test; letters indicate differences within sites. 
After DNM mean pH values slightly increased in all affected sites. Such trends have also been observed in a study by Joensuu (2002), where immediately after DNM the mean pH value increased by 0.6 ; in a study by Marttila (2018) peatland drainage tended to increase $\mathrm{pH}$ levels and in a study by Kalvīte (2019) in majority of study sites pH values also increased after DNM. Nitrogen compounds did not show clear tendencies when periods before and after construction works were compared. Mean concentrations of $\mathrm{N}_{-} \mathrm{NH}_{4}{ }^{+}$and $\mathrm{N}-\mathrm{NO}_{3}{ }^{-}$in all affected sites slightly increased $\left(\mathrm{N}-\mathrm{NH}_{4}{ }^{+}\right.$in sites SP, SP A, SP B significantly ( $p$-values $<0.037)$ ), while TN remained stable or slightly decreased after DNM. Mean concentrations of phosphorus compounds slightly decreased $\left(\mathrm{P}_{-} \mathrm{PO}_{4}{ }^{3-}\right.$ in sites SP, SP A, SP B significantly ( $p$-values $<0.006)$ ) in a period after construction works in all affected sites. Results from different studies for phosphorus are ambiguous. Slight increases (Nieminen et al., 2010), slight decreases (Joensuu et al., 2006) or no effect (Åström et al., 2002) on phosphorus concentrations/exports were observed. In our study sites quite high mean concentrations of DOC were observed. In Finnish study (Marttila et al., 2018) in drained peatland forestry areas concentrations of DOC varied 10.1-41.0 mg/l. In our study sites minimum value of mean DOC concentration was $29.1 \mathrm{mg} / \mathrm{l}$ (Site SP R after construction works), maximum - $49.1 \mathrm{mg} / \mathrm{l}$ (Site SP B before construction works). Effect of DNM was observed regarding significantly decreased mean DOC concentrations in affected sites ( $p$-values $<0.003$ ). DOC concentrations decreased after DNM as reported in other studies (Nieminen et al., 2010; Nieminen et al., 2017a).

In a study by Amatya et al. (2003) where orifice-weir was established in drained temperate forests to reduce peak drainage rates and to store water, total sediment was reduced by $54 \%$ and TP by $30 \%$, however no effect on the export of nitrogen components was observed. On the other hand, in a study by Marttila and Kløve (2010) in drained peatland forests in Finland PFC structure trapped $86 \%$ of suspended solids, $67 \%$ of TP and $65 \%$ of TN. In our study TSS concentrations were reduced by $62 \%$ with sedimentation pond and by $65 \%$ with PFC structure.

Although there are no threshold values for water quality in drainage systems, the guideline value of TSS in accordance with Water Quality Standards for Priority Fish Waters (which in fact is the receiving waterbody Veseta river) is $25 \mathrm{mg} / \mathrm{l}$ (Cabinet of Ministers, 2002). During sampling period, the highest observed values were $786 \mathrm{mg} / \mathrm{lin}$ site SP A and $506 \mathrm{mg} / \mathrm{l}$ in site PFC A. Observed concentrations justify the need and importance of implementation of water protection structures during DNM.

Significant reduction of all other measured parameters by tested water protection structures was not observed, in some cases concentrations of the parameters even slightly increased. However mean $\mathrm{N}-\mathrm{NO}_{3}{ }^{-}$concentrations during sampling period in all study sites were generally low. Although, Water Quality Standards for Surface Waters cannot be directly applied to drainage system ditches, according to the Nitrates Directive and legislation of the Republic of Latvia (Cabinet of Ministers, 2017), the $\mathrm{NO}_{3}^{-}$threshold concentration in drinking water must not exceed $50 \mathrm{mg}^{-1} \mathrm{NO}_{3}{ }^{-}(11.3$ $\mathrm{mg} / \mathrm{l} \mathrm{N}_{-} \mathrm{NO}_{3}{ }^{-}$). In our study sites highest observed concentration of $\mathrm{N}-\mathrm{NO}_{3}{ }^{-}$was $2.32 \mathrm{mg} / \mathrm{l}$ in site PFC R in period after DNM. Also mean $\mathrm{P}_{-} \mathrm{PO}_{4}{ }^{3-}$ concentrations were generally low. According to previously mentioned Water Quality Standards, guideline value is $0.3 \mathrm{mg} / 1 \mathrm{PO}_{4}{ }^{3-}\left(0.098 \mathrm{mg} / 1 \mathrm{P}-\mathrm{PO}_{4}{ }^{3-}\right)$ while the highest observed $\mathrm{P}-\mathrm{PO}_{4}{ }^{3-}$ concentration was $0.111 \mathrm{mg} / \mathrm{l}$ during screening period (before DNM was started) in site PFC.

As nutrient accumulation by the living vegetation is an important facet of the nutrient retention (Huttunen et al., 1996; Bedard-Haughn et al., 2004; Silvan et al., 2005), sampling and assessment of effectiveness of the constructed water protection structures is still ongoing. Eventually after the formation of vegetation in the structures' ponds, effectiveness in reducing plant nutrients could change. In addition, study is being continued to further assess DNM impact on water quality.

Acknowledgements. The study was carried out within the frames of long-term hydrological monitoring in forest ecology station "Vesetnieki" in scientific research forests of Kalsnava forest district.

\section{REFERENCES}

1. Albert E. K., Phelps L. B., Conrad P. 1988. Sedimentation ponds: A review of United States regulations affecting design. International Journal of Surface Mining. Reclamation and Environment, Vol. 2(1), pp. 7-17. https://doi.org/10.1080/09208118808944131

2. Amatya D. M., Skaggs R. W., Gilliam J. W., Hughes J. H. 2003. Effects of Orifice-Weir Outlet on Hydrology and Water Quality of a Drained Forested Watershed. Southern Journal of Applied Forestry, Vol. 27(2), pp. 130-142. https://doi.org/10.1093/sjaf/27.2.130

3. Åström M., Aaltonen E.-K., Koivusaari J. 2002. Impact of forest ditching on nutrient loadings of a small stream-a paired catchment study in Kronoby, W. Finland. Science of The Total Environment, Vol. 297(1-3), pp. $127-140$. https://doi.org/10.1016/S0048-9697(02)00129-8

4. Bedard-Haughn A., Tate K. W., van Kessel C. 2004. Using Nitrogen-15 to Quantify Vegetative Buffer Effectiveness for Sequestering Nitrogen in Runoff. Journal of Environmental Quality, Vol. 33(6), pp. $2252-2262$. https://doi.org/10.2134/jeq2004.2252

5. Cabinet of Ministers. 2002. Regulation No. 118. Regulations Regarding the Quality of Surface Waters and Groundwaters. Rīga: Latvijas Vēstnesis. Available at https://likumi.lv/ta/en/en/id/60829 (accessed on 10/10/2021)

6. Cabinet of Ministers. 2014. Regulation No.600. Procedure for the granting of state and European Union support in the form of an open call for projects for the "Investment in tangible assets". Rīga: Latvijas Vēstnesis. Available at https://likumi.lv/ta/id/269868kartiba-kada-pieskir-valsts-un-eiropas-savienibas-atbalstu-atklatu-projektu-konkursu-veida-pasakumam-ieguldijumimaterialajos (accessed on 10/10/2021) 
7. Cabinet of Ministers. 2017. Regulation No. 671. Mandatory harmlessness and quality requirements for drinking water, and the procedures for monitoring and control thereof. Rīga: Latvijas Vēstnesis. Available at https://likumi.lv/ta/en/en/id/295109 (accessed on 10/10/2021)

8. Finér L., Čiuldienė D., Libieté Z. Lode E., Nieminen M., Pierzgalski E., Ring E., Strand L., Sikström U. 2018. WAMBAF - Good Practices for Ditch Network Maintenance to Protect Water Quality in the Baltic Sea Region. Available at https://www.lammc.lt/data/public/uploads/2019/02/drainage_guidelines_25_2018_wambaf.pdf (accessed on 10/10/2021)

9. Grung M., Meland S., Ruus A., Ranneklev S., Fjeld E., Kringstad A., Rundberget J. T., Dela Cruz M., Christensen J. H. 2021. Occurrence and trophic transport of organic compounds in sedimentation ponds for road runoff. Science of the Total Environment, Vol. 751, 141808. https://doi.org/10.1016/j.scitotenv.2020.141808

10. Huttunen A., Heikkinen K., Ihme,R. 1996. Nutrient retention in the vegetation of an overland flow treatment system in northern Finland. Aquatic Botany, Vol. 55(1), pp. 61-73. https://doi.org/10.1016/0304-3770(96)01053-4

11. Hynninen A., Hamberg L., Nousiainen H., Korpela L., Nieminen M. 2011. Vegetation composition dynamics in peatlands used as buffer areas in forested catchments in southern and central Finland. Plant Ecology, Vol. 212(11), pp. 1803-1818. https://doi.org/10.1007/s11258-011-9950-y

12. Joensuu S., Ahti E., Vuollekoski M. 2002. Effects of ditch network maintenance on the chemistry of run-off water from peatland forests. Scandinavian Journal of Forest Research, Vol. 17(3), pp. 238-247. https://doi.org/10.1080/028275802753742909

13. Joensuu S., Ahti E., Vuollekoski M. 1999. The effects of peatland forest ditch maintenance on suspended solids in runoff. Boreal Environment Research, Vol. 4, pp. 343-355.

14. Joensuu S., Vuollekoski M., Karosto K. 2006. Kunnostusojitusten pitkäaikaisvaikutuksia. Suom. Ympäristö-Finn. Environ. Miljön I Finl, Vol. 816, pp. 83-90. (in Finnish)

15. Kalvite Z., Libiete Z., Klavins I. 2019. The efficiency of forest drainage system sedimentation ponds in the context of water quality. Research for Rural Development, pp. 95-102. https://doi.org/10.22616/rrd.25.2019.015

16. Kløve B. 2000. Retention of suspended solids and sediment bound nutrients from peat harvesting sites with peak runoff control, constructed floodplains and sedimentation ponds. Boreal Environment Research.

17. LEGMC. 2020. Report on surface water and groundwater condition in 2019. (in Latvian). Available at https://videscentrs.lvgmc.lv/files/Udens/udens_kvalitate/VPUK_2019_FINAL_26102020.pdf (accessed on 10/10/2021)

18. Le Viol I., Mocq J., Julliard R., Kerbiriou C. 2009. The contribution of motorway stormwater retention ponds to the biodiversity of aquatic macroinvertebrates. Biological Conservation, Vol. 142(12), pp. 3163-3171. https://doi.org/10.1016/i.biocon.2009.08.018

19. Marttila H., Karjalainen S. M., Kuoppala M., Nieminen M. L., Ronkanen A. K., Kløve B., Hellsten S. 2018. Elevated nutrient concentrations in headwaters affected by drained peatland. Science of the Total Environment, Vol. 643, pp. 1304-1313. https://doi.org/10.1016/j.scitotenv.2018.06.278

20. Marttila H., Kløve B. 2010. Managing runoff, water quality and erosion in peatland forestry by peak runoff control. Ecological Engineering. https://doi.org/10.1016/j.ecoleng.2010.04.002

21. Meland S., Sun Z., Sokolova E., Rauch S., Brittain J. E. 2020. A comparative study of macroinvertebrate biodiversity in highway stormwater ponds and natural ponds. Science of the Total Environment, Vol. 740, ID 140029. https://doi.org/10.1016/j.scitotenv.2020.140029

22. Mendiburu F. 2020. Package "agricolae" Title Statistical Procedures for Agricultural Research. In Statistical procedures for agricultural research.

23. Nieminen M. 2004. Export of dissolved organic carbon, nitrogen and phosphorus following clear-cutting of three Norway spruce forests growing on drained peatlands in southern Finland. Silva Fennica, Vol. 38, ID 422. https://doi.org/10.14214/sf.422

24. Nieminen M., Ahti E., Koivusalo H., Mattsson T., Sarkkola S., Laurén A. 2010. Export of suspended solids and dissolved elements from peatland areas after ditch network maintenance in south-central Finland. Silva Fennica, Vol. 44, IID 161. https://doi.org/10.14214/sf.161

25. Nieminen M., Palviainen M., Sarkkola S., Laurén A., Marttila H., Finér L. 2017. A synthesis of the impacts of ditch network maintenance on the quantity and quality of runoff from drained boreal peatland forests. Ambio, Vol. 47, pages 523-534 pp. 1-12. https://doi.org/10.1007/s13280-017-0966-y

26. Nieminen M., Sallantaus T., Ukonmaanaho L., Nieminen T. M., Sarkkola S. 2017. Nitrogen and phosphorus concentrations in discharge from drained peatland forests are increasing. Science of the Total Environment, Vol. 609, pp. 974-981. https://doi.org/10.1016/j.scitotenv.2017.07.210

27. Paavilainen E., Päivänen J. 1995. Peatland forestry: ecology and principles. Springer Science \& Business Media. https://doi.org/10.1007/978-3-662-03125-4

28. R Development Core Team. 2020. R Development Core Team, R: a language and environment for statistical computing. In R: A Language and Environmental for Estatistical Computing.

29. Silvan N., Tuittila E. S., Kitunen V., Vasander H., Laine J. 2005. Nitrate uptake by Eriophorum vaginatum controls N2O production in a restored peatland. Soil Biology and Biochemistry, Vol. 37(8), pp. $1519-1526$. https://doi.org/10.1016/j.soilbio.2005.01.006

30. State Forest Service. 2021. 2020 public report. (in Latvian). Available at https://www.zm.gov.lv/public/files/CMS_Static_Page_Doc/00/00/02/09/48/VMD_publiskais_parskats_2020.pdf (accessed on 10/10/2021)

31. Sun Z., Brittain J. E., Sokolova E., Thygesen H., Saltveit S. J., Rauch S., Meland S. 2018. Aquatic biodiversity in sedimentation ponds receiving road runoff - What are the key drivers? Science of the Total Environment, Vol. 610-611, pp. 1527-1535. https://doi.org/10.1016/j.scitotenv.2017.06.080 
32. Tunçsiper B. 2020. Nitrogen removal in an aerobic gravel filtration-sedimentation pond-constructed wetland-overland flow system treating polluted stream waters: Effects of operation parameters. Science of the Total Environment, Vol. 746, 140577. https://doi.org/10.1016/j.scitotenv.2020.140577

33. Wickham H. 2016. ggplot2 Elegant Graphics for Data Analysis (Use R!). Springer. https://doi.org/10.1007/978-3-319-24277-4

34. Zapico I., Laronne J. B., Meixide C., Sánchez Castillo L., Martín Duque J. F. 2021. Evaluation of sedimentation pond performance for a cleaner water production from an open pit mine at the edge of the Alto Tajo Natural Park. Journal of Cleaner Production, Vol. 280, 124408. https://doi.org/10.1016/j.jclepro.2020.124408 